\title{
Foreign Languages' Planning in the Post-Taliban Afghanistan
}

\author{
Dr. Ayaz Ahmad* Ms. Sana Hussan ${ }^{\dagger}$ Mr. Muhammad Safiullah ${ }^{\ddagger}$
}

\begin{abstract}
This paper analyses the management of foreign languages in the language planning of Afghanistan after the fall of Taliban. The analyses assess the suitability of foreign languages performing developmental and peace-making roles in domains where distribution of power is contested by the Afghan ethnolinguistic groups. Primary data of the paper comes from a questionnaire based survey and follow-up interviews. Analysis reveals the presence of various modern languages such as French, German, Russian and English in Afghanistan. The acceptance of foreign languages especially English is overwhelming in Afghanistan. Among foreign languages, English happens to be the most vigorous and promising language. However, a significant portion of Afghans oppose the growing influence and power for the foreign languages in Afghanistan. The paper notes, an uneven spread of English as the dominant foreign language in Afghanistan. Therefore, foreign languages' role in development and peace-making may not be achieved due to lack of equal access. The paper recommends a wide-range of interventions to help in making foreign languages a resource for development and peace-making. The intervention includes social, economic and political equality and equal opportunities in learning of foreign languages. It is also emphasised that the promotion of local languages is not to be affected by the availability of foreign languages.
\end{abstract}

Key Words: Afghanistan, Foreign Languages, Language Planning, English, French, German, Russian

\section{Introduction}

The multilingual state of Afghanistan has historically remained a route and destination of migration from and to Central Asia. The local languages had been foreign at some point in the history. However, Some languages like English, German, French and Russian have contemporary currency as lingua franca, therefore, their spread arouse the curiosity of researchers and scholars. The spread of these languages began in twentieth century. Their mutual interaction

\footnotetext{
*Lecturer, Department of English,Abdul Wali Khan University Mardan, Mardan, KP, Pakistan. Email: ayazmardan@gmail.com

${ }^{\dagger}$ MPhil Scholar (English), Department of English, Abdul Wali Khan University Mardan, Mardan, KP, Pakistan.

${ }^{\dagger}$ Research Assistant, Humanity Research Council, Islamabad, Pakistan.
} 
and contact with local language speakers (and their languages) offer significant research problem in language planning studies.

To understand this problem, the paper first ascertains the objectives and methodology of the study. Then, a background of foreign language learning in the pre-Taliban era is explored. The review of Pre-Taliban era constitutes the background to the post-Taliban era language planning as the leading trends in the pre-Taliban era planning continue in the post-Taliban era planning. The postTaliban era discussion is based on the survey and interviews data. The analysis and discussion explore the role of role of foreign languages, especially English in domains where access to power is contested. The analysis identifies various foreign languages and compares them with English. Role (cooperative and resisting) of local languages (especially Pashto and Dari) is also analysed. Last section concludes the paper and provide general language planning guidelines to help in improving language planning for foreign languages play a positive role in development and peace-making.

\section{Literature Review}

Language makes the existence of social life possible due to its centrality in performing social function through communication (Dunne, Pryor, \& Yates, 2005 , p. 93). German political philosopher, Herder had shown the vital connection between the language a society speaks and the national character they exhibit (Miskelly \& Noce, 2002, p. 234). This idea has been subsequent endorsed by the scholars of sociolinguistics such as Wardhaugh (1987), Crystal (2000), Phillipson (1992), Mac Giolla Chriost (2003) and Ferguson (2006). The relationship between the political unity and peace and economic prosperity was not taken seriously. The leading European linguist and founder of modern linguistics, Saussure busied himself with delimiting the study of linguistics he threw out the baby of social aspects with the bath water. He argued that while social functions are important in the system of language (as the humans who speak a language use it only in social setting), however, he considered the investigation of link between society and language beyond the scope of linguistics (de Saussure, 1915).

While Saussure was closing the doors of relation between language and society, the Soviet scholars (whose work largely remained forgotten to the western audience due to neglect and lack of translations) found sufficient proof that language and society are related. Voloshinov (1973) established in 1921 the vitality of social in linguistics. The Soviet political leadership was also interested in the language problem. Lenin (1964) postulated in nascent days of Soviet Union that a prosperous and unified nation is not necessarily the one with one language. He identified the essential link between language and the collective identity of the people who make multilingual nations. He spoke in favour of 
equality of languages in the communist state. Stalin (1953/1913) followed the footsteps of Lenin, however, while Lenin was more of a thinker, Stalin was a practical man. He laid down some political conditions where a nation is to be identified and their right of sovereignty respected. He linked nationhood to territoriality and existence of a common character (language being the primary one). Though the critics of language planning in Soviet Union point to the fact that the proclaimed statements about language were not put into practice, but the arguments and debate produced good scholarship of language planning in the Soviet period.

Despite earlier hiccups in recognizing the social dimension of language as the proper part of linguistic scholarship, the field gradually emerged as a respected field and branch of linguistics. The later part of twentieth century saw many great names contributing to the field such as Elana Shohamy, Ferguson, Weinrich, Joshua A. Fishman, Herold Shiffman, Robert Phillipson, Bernard Spolsky, Tariq Rahman and Nekvapil. The list of the illustrious contributors extends into thousand. Therefore, this study economises on the studies that underlie this research paper and focus directly on the theoretical construct used here. Spolsky (2004), identified, "Tripartite division of language policy into (1) language practices, language beliefs and ideology, and (2)the explicit policies and plans resulting from (3) language-management or planning activities that attempt to modify practices and ideologies of a community." $\mathrm{He}$ further, proposes four factors of language policy, first he mentions three dimensions of language policy formation: (1) language practices and ideology, (2) undertaken language management and (3) aspired changes in practices and ideology. Second he emphasises comprehensiveness of language policy that subsumes all levels and verities of languages (whether named or not). Third, language policy operates in all language communities of whatever size. Fourth, language policy is represented through the complex ecological relation of a language and the community that speaks it (Spolsky, 2004).

Taking this concept and applying it to the concept of a national state, Ahmad and Khan (2016) identified the planning as a cyclic process where accommodation produces good effects of peace, unity and prosperity while suppression and exclusion produce the negative result of disunity, resistance and possible violence. With this framework in mind the study adopts the following research methodology.

\section{Materials and Methods}

This part contains the key facts about the research such as research objectives, questions, nature and source of data, tools of data collection and analysis. The study is essentially qualitative in nature however; some descriptive statistics is also used. 


\section{Objective of the Study}

The leading objective of this study was to find out the suitability of foreign languages to perform developmental and peace-making roles in domains where distribution of power is contested by the Afghan ethnolinguistic groups. With this objective in mind following questions are addressed in this paper:

1. What are the main characteristics of Afghan language planning in twentieth century?

2. Who among Afghans are the supporters/opposers of foreign language learning?

3. What are the prospects of English language in various domains?

4. What kind of planning measures for further improving language planning in Afghanistan?

\section{Population and Sample}

Population of this study includes participants in the domains of power including government (legislature, judiciary and executive), education, workplace (economy), social change and language landscape. This population of Afghanistan is expected to more educated, economically stable, mature and socially privileged than the common Afghan population. This attributes make such people active participants in the domains of power. The sample of this study is 226 arising from five urbanized centres in Afghanistan i.e. Kabul, Mazar-eSharif, Herat, Kandahar and Jalalabad covering respectively the central, northern, western, eastern and southern areas of Afghanistan. This sampling procedure follows the rationale of an earlier study by WAK Foundation of Afghanistan (Wak Foundation for Afghanistan (WFA), July 1999). In terms of ethnicity, age, gender, education, professional experience, area of residence (representing urban or rural areas) and income the sample has the following distribution.

\begin{tabular}{|c|c|c|c|c|c|}
\hline & & & able1: G & nder & \\
\hline & & Frequency & Percent & Valid Percent & $\begin{array}{c}\text { Cumulative } \\
\text { Percent }\end{array}$ \\
\hline & Female & 100 & 44.2 & 44.2 & 44.2 \\
\hline Valid & Male & 126 & 55.8 & 55.8 & 100.0 \\
\hline & Total & 226 & 100.0 & 100.0 & \\
\hline
\end{tabular}




\begin{tabular}{|c|c|c|c|c|c|}
\hline \multicolumn{7}{|c|}{ Table 2: Age of the respondent showing maturity } \\
\hline \multirow{4}{*}{} & Age 1-19 & 48 & 21.2 & 21.2 & 21.2 \\
\hline \multirow{4}{*}{ Valid } & age 20-29 & 80 & 35.4 & 35.4 & 56.6 \\
\cline { 2 - 6 } & age 30-49 & 58 & 25.7 & 25.7 & 82.3 \\
\cline { 2 - 6 } & age 50 and above & 40 & 17.7 & 17.7 & 100.0 \\
\cline { 2 - 6 } & Total & 226 & 100.0 & 100.0 & \\
\hline
\end{tabular}

\begin{tabular}{|c|c|c|c|c|c|}
\hline \multicolumn{7}{|c|}{ Table 3: Ethnicity } \\
\hline \multirow{4}{*}{} & Frequency & Percent & $\begin{array}{c}\text { Valid } \\
\text { Percent }\end{array}$ & $\begin{array}{c}\text { Cumulative } \\
\text { Percent }\end{array}$ \\
\hline \multirow{4}{*}{ Valid } & Pashtun & 90 & 39.8 & 39.8 & 39.8 \\
\cline { 2 - 6 } & Tajik & 83 & 36.7 & 36.7 & 76.5 \\
\cline { 2 - 6 } & Uzbek & 18 & 8.0 & 8.0 & 84.5 \\
\cline { 2 - 6 } & Turkoman & 8 & 3.5 & 3.5 & 88.1 \\
\cline { 2 - 6 } & Hazara & 18 & 8.0 & 8.0 & 96.0 \\
\cline { 2 - 6 } & other minorities & 9 & 4.0 & 4.0 & 100.0 \\
\cline { 2 - 6 } & Total & 226 & 100.0 & 100.0 & \\
\hline
\end{tabular}

Table 4: Rural and Urban residence

\begin{tabular}{|c|c|c|c|c|c|}
\hline \multicolumn{2}{|c|}{} & Frequency & Percent & Valid Percent & $\begin{array}{c}\text { Cumulative } \\
\text { Percent }\end{array}$ \\
\hline \multirow{4}{*}{ Valid } & rural & 87 & 38.5 & 38.5 & 38.5 \\
\cline { 2 - 6 } & urban & 109 & 48.2 & 48.2 & 86.7 \\
\cline { 2 - 6 } & expat & 30 & 13.3 & 13.3 & 100.0 \\
\cline { 2 - 6 } & Total & 226 & 100.0 & 100.0 & \\
\hline
\end{tabular}




\begin{tabular}{|c|c|c|c|c|c|}
\hline \multicolumn{6}{|c|}{ Table 5: Level of education } \\
\hline & & Frequency & Percent & Valid Percent & $\begin{array}{c}\text { Cumulative } \\
\text { Percent }\end{array}$ \\
\hline \multirow{8}{*}{ Valid } & no education & 9 & 4.0 & 4.0 & 4.0 \\
\hline & Primary & 59 & 26.1 & 26.1 & 30.1 \\
\hline & Secondary & 12 & 5.3 & 5.3 & 35.4 \\
\hline & higher secondary & 45 & 19.9 & 19.9 & 55.3 \\
\hline & Graduate & 63 & 27.9 & 27.9 & 83.2 \\
\hline & Postgrad & 30 & 13.3 & 13.3 & 96.5 \\
\hline & PhD/MPhil & 8 & 3.5 & 3.5 & 100.0 \\
\hline & Total & 226 & 100.0 & 100.0 & \\
\hline \multicolumn{6}{|c|}{ Table 6: Professional experience } \\
\hline & & Frequency & Percent & $\begin{array}{c}\text { Valid } \\
\text { Percent }\end{array}$ & $\begin{array}{c}\text { Cumulative } \\
\text { Percent }\end{array}$ \\
\hline \multirow{5}{*}{ Valid } & no experience & 68 & 30.1 & 30.1 & 30.1 \\
\hline & less than 1 year & 35 & 15.5 & 15.5 & 45.6 \\
\hline & 1-10 years' experience & 88 & 38.9 & 38.9 & 84.5 \\
\hline & $\begin{array}{c}\text { more than } 10 \text { year } \\
\text { experience }\end{array}$ & 35 & 15.5 & 15.5 & 100.0 \\
\hline & Total & 226 & 100.0 & 100.0 & \\
\hline
\end{tabular}

\begin{tabular}{|c|c|c|c|c|c|}
\hline \multicolumn{7}{|c|}{ Table 7: Job position } \\
\hline \multirow{7}{*}{} & Frequency & Percent & Valid Percent & $\begin{array}{c}\text { Cumulative } \\
\text { Percent }\end{array}$ \\
\hline \multirow{4}{*}{ Valid } & Jobless & 35 & 15.5 & 15.5 & 15.5 \\
\cline { 2 - 6 } & entry level & 82 & 36.3 & 36.3 & 51.8 \\
\cline { 2 - 6 } & mid admin level & 64 & 28.3 & 28.3 & 80.1 \\
\cline { 2 - 6 } & top admin level & 45 & 19.9 & 19.9 & 100.0 \\
\cline { 2 - 6 } & Total & 226 & 100.0 & 100.0 & \\
\hline
\end{tabular}




\section{Tools for Data Collection and Analysis}

Primary data of this study derives from a questionnaire based survey (in section 5 of this paper it is referred as Afghan Language Planning Survey, 2010) and interviews from 12 selected experts (in section 5, it is referred as Expert Opinion, 2010). Statistical Package for Social Sciences (SPSS v.25) is used for analysing the data. Data interpretation is undertaken with the help of Spolsky (2004) four components theoretical model and Hybrid Language Policy Planning model of Ahmad and Khan (2016) explaining the role of language policy planning in national integration. Some of the primary and most of the secondary data of this study is taken from archival and publish sources for the elaboration of research framework and validation and explanation of analysis and literature review.

\section{Pre-Taliban Language Planning}

This section briefly outlines the evolution of foreign language planning in the $20^{\text {th }}$ century, a century preceding and making a base for the current planning. In the course of discussion in these section major changes in politics, society, economy and culture of Afghanistan are related to foreign languages' role (in terms of language practices, beliefs and management) in the Afghan domains of power. Pertinent examples form government, education; economy and social change are included so the contours of language planning trends become lucid. Various constitutions that were promulgated during the mentioned period along official documents including the gazette styled "Afghan Yearbook" have helped in forming the assessment of top-down language planning. The scope of foreign languages is limited in this paper to modern European languages i.e. English, German, French and Russian.

Afghanistan being situated at the cross road of migration, war and trade routes of Asia, has been home to introduction of many foreign languages that were brought by the speakers when they came to Afghanistan. As the origin of most of the contemporary indigenous languages is traceable to foreign sources, the notable example of languages that originated in a foreign land getting localized include Arabic, Dari, Pashto, Uzbeki, Turkmani etc. The archaeological evidence suggest that the languages in ancient Afghanistan were quite different from what languages are spoken in contemporary Afghanistan (Habibi, 1967).

Due to two Anglo Afghan wars, Britain held Afghanistan in its sphere of influence through $19^{\text {th }}$ century. The external control made Afghan rulers reluctant to let the foreign influence (especially of Britain) grow and threaten her sovereignty. While the ruler resisted British influence and resisted the spread of English language, lack of diplomatic contact with other languages remained impossible due to the British control on relation with other states. The effect of 
this control emerged in the absence of modern European languages from Afghanistan.

The beginning of $20^{\text {th }}$ century ushered three important developments transformed the language planning context for Afghanistan. First, the World War I changed the global balance of power in the Europe. The participation of Britain in this war gave courage to Afghan elite to successfully attempt the end of suzerainty established through the second Anglo-Afghan war. The third AngloAfghan war gave Afghan rulers the opportunity to establish relations with other foreign states and benefit from introducing their languages in their education system (Ahmed \& Institute for Global Dialogue., 2001). Second, modernization in health, production, communication, arms etc. at global level started to pressure the rulers to introduce foreign languages as means of getting in touch with the developed states in order to facilitate modernization in Afghanistan. Third, the traditional education in Afghanistan came under attack from progressive figures such as Tarzi. The reformist movement though intended at the political reforms such as the Mashroota Awal and Mashroota Doyim inevitably advocated learning of foreign languages as means of development and prosperity in Afghanistan (Tarzi, $1334 \mathrm{AH}$ ). The internal pressure of reform and modernization bore fruit when modern education was finally inaugurated in 1904 by Amir Habibullah Khan.

The reign of Amir Habibullah Khan initiated the teaching of foreign languages by launching modern educational institutions like Habibia, where French, German and English was used as medium of instruction and learning resources for sciences, medicine and engineering etc. Afghan court subsequently hired services of translator of French, English and Turkish to facilitate international relations (Government of Afghanistan, 1935). However, out of French, German, Russian and English, it was English that dominated the process of modernization in Afghanistan. Firstly, Indian Muslims maintained close contact with Afghan rulers. Secondly, the Indian Muslim teachers found good professional opportunities in Afghanistan so they preferred teaching in the newly inaugurated institutions. Hiring, a Muslim English teacher was more acceptable to the rulers, students and community in Afghanistan. Thus the inauguration of education institutions offering modernized education in Afghanistan increased the cultivation of English language there.

Britain ruled British India till the end of the World War II. Her exit from the sub-continent coincided with the rise of United States of America (USA). Thus, USA became successor of the Britain in international politics. USA, kept the promotion of English alive globally. In Afghanistan too, USA's aid agency USAID (United States Agency for International Development) supported promotion of English language as part of development projects for education in Afghanistan. However, the promotion of English was seriously challenged by 
Russian language, as diplomatic and people to people relations strengthened between USSR and Afghanistan.

USSR inherited the geopolitical legacy of Tsarist Russia. In 1917, the borders of Soviet Central Asia were shared with Afghanistan in Tajikistan, Uzbekistan and Turkmenistan. The Third Anglo-Afghan war opened the doors of international diplomacy and relations for Afghanistan. USSR was one of the earliest state to come closer to Afghanistan. Initially, USSR offered financial support to Afghanistan. However, the relations soon expanded as USSR started to assist in developmental project (in a bid to outmanoeuvre USA), training of personnel and setting of educational institutions in Afghanistan such as polytechnic institute in 1960s (Sadat, March 2004). The Soviet education was the best and freely available opportunity for any Afghan willing to cross the border and go to USSR. The Soviet education was only available in Russian language. Thus the expanded relation in 1960s not only strengthened the support for communist ideology, it also increased the predominance of Russian in Afghanistan. The treaty of 1969 for example greatly increased the presence of Russian speaking technical and educational experts in Afghanistan. Later, this influence resulted in the Saur revolution and entry of Soviet forces in Afghanistan (Muneeb, 2002). The establishment of People Democratic Party of Afghanistan's rule provided great impetus to the promotion of Russian language. English language was associated by the PDPA ideologues with the capitalist domination so its presence in education was significantly limited to a department in Kabul University and international radio transmission (mainly targeting international audience for propaganda purposes).

Though, the Saur revolution resulted in a set-back for the spread of English language in 1970s and 1980s. A significant number of Afghans immigrated to Pakistan. These refugees were initially provided education in camps where English language was included in the curriculum. There was no strict attempt to segregate Pashto speaking Afghans from the local Pashtun population. Afghan refugees routinely preferred to take admission in local schools and colleges where English was a preferred medium for education (Ekanayake, 2004). So, the Afghans who opted to migrate during civil war and resistance against the Kabul received education in English language across border in Pakistan. During the heydays of the resistance Peshawar bloomed with many English language centres. Afghans who aspired to immigrate to the Anglophone states or pursue higher education in Pakistan eagerly participated in taking courses to improve their speaking, reading, writing and listening skills there.

English, though remained a dominant language in Afghanistan, however, French and German learning and teaching was also pursued. Germany and France remained a preferred destination for sending students for higher education through Afghan government supported scholarships. French and German teachers were also hired to teach in Habibiya, Istiqlal and Nijat schools offered 
these languages as separate courses in grade 7 onwards (Government of Afghanistan, 1945-46). Though, this education only remained limited to the elite circle and never reached beyond cities into the distant rural peripheries, the modernized youth of Kabul came to know about western ideals and readily imbibed the culture and ideals (Dupree, 2002; Dupree \& Gouttierre, 2001).

\section{Post-Taliban Language planning}

The twentieth century Afghanistan developed some lasting features of Afghan language planning. The degree of dependence (political and aid) reciprocated in the degree of allowing the language of that particular state to flourish through elite educational institutions, technical facilities and training of personnel. The elite class became the focus of foreign language domination and the masses normally remained untouched by the prevalence of language in domains of power. However, such domination produced a demand for learning such languages as aspirant in the non-elite circles found in those languages a means to ensure upward economic, social and political mobility. The presence in domains of power specifically in education, workplace and government provided the source state of the language e.g. Britain and USA through English, Soviet Union through Russian, France through French and Germany through German languages, an opportunity to play decisive role in those domains and thereby allow entry only those who conformed with their underlying political, economic and social interests.

These trends are verified through the Afghan Language Planning Survey, 2010 and Expert Interviews, 2010. The significant portions of survey are here presented in tables and discussion that follows analyses the data. Interview based insight is used in interpreting outcome of the conducted survey.

\section{Table 8: Crosstabluation of Gender, Ethnicity and Second exochthonous language of the respondents (First choice in communication)}

\begin{tabular}{|c|c|c|c|c|c|c|}
\hline \multirow{2}{*}{\multicolumn{4}{|c|}{$\begin{array}{l}\text { Second exochthonous language of the respondents } \\
\text { (First choice in communication) }\end{array}$}} & \multicolumn{2}{|c|}{ Gender } & \multirow{3}{*}{$\begin{array}{c}\text { Total } \\
28\end{array}$} \\
\hline & & & & \multirow{2}{*}{$\begin{array}{c}\text { Female } \\
8\end{array}$} & \multirow{2}{*}{$\begin{array}{c}\text { Male } \\
20\end{array}$} & \\
\hline \multirow{6}{*}{ none } & \multirow{5}{*}{ Count } & \multirow{4}{*}{ Ethnicity } & Pashtun & & & \\
\hline & & & Tajik & 9 & 15 & 24 \\
\hline & & & Turkoman & 1 & 0 & 1 \\
\hline & & & Hazara & 1 & 0 & 1 \\
\hline & & \multicolumn{2}{|c|}{ Total } & 19 & 35 & 54 \\
\hline & $\%$ within & Ethnicity & Pashtun & $42.1 \%$ & $57.1 \%$ & $51.9 \%$ \\
\hline
\end{tabular}




\begin{tabular}{|c|c|c|c|c|c|c|}
\hline & \multirow[t]{4}{*}{ Gender } & & Tajik & $47.4 \%$ & $42.9 \%$ & $44.4 \%$ \\
\hline & & & Turkoman & $5.3 \%$ & $0.0 \%$ & $1.9 \%$ \\
\hline & & & Hazara & $5.3 \%$ & $0.0 \%$ & $1.9 \%$ \\
\hline & & \multicolumn{2}{|c|}{ Total } & $100.0 \%$ & $100.0 \%$ & $100.0 \%$ \\
\hline \multirow{14}{*}{ English } & \multirow{7}{*}{ Count } & \multirow{6}{*}{ Ethnicity } & Pashtun & 12 & 18 & 30 \\
\hline & & & Tajik & 9 & 32 & 41 \\
\hline & & & Uzbek & 6 & 3 & 9 \\
\hline & & & Turkoman & 3 & 4 & 7 \\
\hline & & & Hazara & 13 & 2 & 15 \\
\hline & & & $\begin{array}{c}\text { other } \\
\text { minorities }\end{array}$ & 3 & 1 & 4 \\
\hline & & \multicolumn{2}{|c|}{ Total } & 46 & 60 & 106 \\
\hline & \multirow{7}{*}{$\begin{array}{c}\% \text { within } \\
\text { Gender }\end{array}$} & \multirow{6}{*}{ Ethnicity } & Pashtun & $26.1 \%$ & $30.0 \%$ & $28.3 \%$ \\
\hline & & & Tajik & $19.6 \%$ & $53.3 \%$ & $38.7 \%$ \\
\hline & & & Uzbek & $13.0 \%$ & $5.0 \%$ & $8.5 \%$ \\
\hline & & & Turkoman & $6.5 \%$ & $6.7 \%$ & $6.6 \%$ \\
\hline & & & Hazara & $28.3 \%$ & $3.3 \%$ & $14.2 \%$ \\
\hline & & & $\begin{array}{c}\text { other } \\
\text { minorities }\end{array}$ & $6.5 \%$ & $1.7 \%$ & $3.8 \%$ \\
\hline & & \multicolumn{2}{|c|}{ Total } & $100.0 \%$ & $100.0 \%$ & $100.0 \%$ \\
\hline \multirow{8}{*}{ German } & \multirow{4}{*}{ Count } & \multirow{3}{*}{ Ethnicity } & Pashtun & 0 & 1 & 1 \\
\hline & & & Tajik & 1 & 2 & 3 \\
\hline & & & $\begin{array}{c}\text { other } \\
\text { minorities }\end{array}$ & 0 & 2 & 2 \\
\hline & & \multicolumn{2}{|c|}{ Total } & 1 & 5 & 6 \\
\hline & \multirow{4}{*}{$\begin{array}{c}\% \text { within } \\
\text { Gender }\end{array}$} & \multirow{3}{*}{ Ethnicity } & Pashtun & $0.0 \%$ & $20.0 \%$ & $16.7 \%$ \\
\hline & & & Tajik & $100.0 \%$ & $40.0 \%$ & $50.0 \%$ \\
\hline & & & $\begin{array}{c}\text { other } \\
\text { minorities }\end{array}$ & $0.0 \%$ & $40.0 \%$ & $33.3 \%$ \\
\hline & & \multicolumn{2}{|c|}{ Total } & $100.0 \%$ & $100.0 \%$ & $100.0 \%$ \\
\hline \multirow{2}{*}{ French } & \multirow{2}{*}{ Count } & \multirow{2}{*}{ Ethnicity } & Tajik & 7 & 2 & 9 \\
\hline & & & Hazara & 2 & 0 & 2 \\
\hline
\end{tabular}




\begin{tabular}{|c|c|c|c|c|c|c|}
\hline & & & $\begin{array}{c}\text { other } \\
\text { minorities }\end{array}$ & 3 & 0 & 3 \\
\hline & & \multicolumn{2}{|c|}{ Total } & 12 & 2 & 14 \\
\hline & \multirow{4}{*}{$\begin{array}{c}\% \text { within } \\
\text { Gender }\end{array}$} & \multirow{3}{*}{ Ethnicity } & Tajik & $58.3 \%$ & $100.0 \%$ & $64.3 \%$ \\
\hline & & & Hazara & $16.7 \%$ & $0.0 \%$ & $14.3 \%$ \\
\hline & & & $\begin{array}{c}\text { other } \\
\text { minorities }\end{array}$ & $25.0 \%$ & $0.0 \%$ & $21.4 \%$ \\
\hline & & \multicolumn{2}{|c|}{ Total } & $100.0 \%$ & $100.0 \%$ & $100.0 \%$ \\
\hline \multirow{8}{*}{ Russian } & \multirow{4}{*}{ Count } & \multirow{3}{*}{ Ethnicity } & Pashtun & 8 & 10 & 18 \\
\hline & & & Tajik & 1 & 1 & 2 \\
\hline & & & Uzbek & 4 & 4 & 8 \\
\hline & & \multicolumn{2}{|c|}{ Total } & 13 & 15 & 28 \\
\hline & \multirow{4}{*}{$\begin{array}{c}\% \text { within } \\
\text { Gender }\end{array}$} & \multirow{3}{*}{ Ethnicity } & Pashtun & $61.5 \%$ & $66.7 \%$ & $64.3 \%$ \\
\hline & & & Tajik & $7.7 \%$ & $6.7 \%$ & $7.1 \%$ \\
\hline & & & Uzbek & $30.8 \%$ & $26.7 \%$ & $28.6 \%$ \\
\hline & & \multicolumn{2}{|c|}{ Total } & $100.0 \%$ & $100.0 \%$ & $100.0 \%$ \\
\hline \multirow{6}{*}{ Arabic } & \multirow{3}{*}{ Count } & \multirow{2}{*}{ Ethnicity } & Pashtun & 4 & 3 & 7 \\
\hline & & & Tajik & 1 & 3 & 4 \\
\hline & & \multicolumn{2}{|c|}{ Total } & 5 & 6 & 11 \\
\hline & \multirow{3}{*}{$\begin{array}{c}\% \text { within } \\
\text { Gender }\end{array}$} & \multirow{2}{*}{ Ethnicity } & Pashtun & $80.0 \%$ & $50.0 \%$ & $63.6 \%$ \\
\hline & & & Tajik & $20.0 \%$ & $50.0 \%$ & $36.4 \%$ \\
\hline & & \multicolumn{2}{|c|}{ Total } & $100.0 \%$ & $100.0 \%$ & $100.0 \%$ \\
\hline \multirow{6}{*}{ Urdu } & \multirow{3}{*}{ Count } & \multirow{2}{*}{ Ethnicity } & Pashtun & 4 & 2 & 6 \\
\hline & & & Uzbek & 0 & 1 & 1 \\
\hline & & \multicolumn{2}{|c|}{ Total } & 4 & 3 & 7 \\
\hline & \multirow{3}{*}{$\begin{array}{c}\% \text { within } \\
\text { Gender }\end{array}$} & \multirow{2}{*}{ Ethnicity } & Pashtun & $100.0 \%$ & $66.7 \%$ & $85.7 \%$ \\
\hline & & & Uzbek & $0.0 \%$ & $33.3 \%$ & $14.3 \%$ \\
\hline & & \multicolumn{2}{|c|}{ Total } & $100.0 \%$ & $100.0 \%$ & $100.0 \%$ \\
\hline \multirow{2}{*}{ Total } & \multirow{2}{*}{ Count } & \multirow{2}{*}{ Ethnicity } & Pashtun & 36 & 54 & 90 \\
\hline & & & Tajik & 28 & 55 & 83 \\
\hline
\end{tabular}




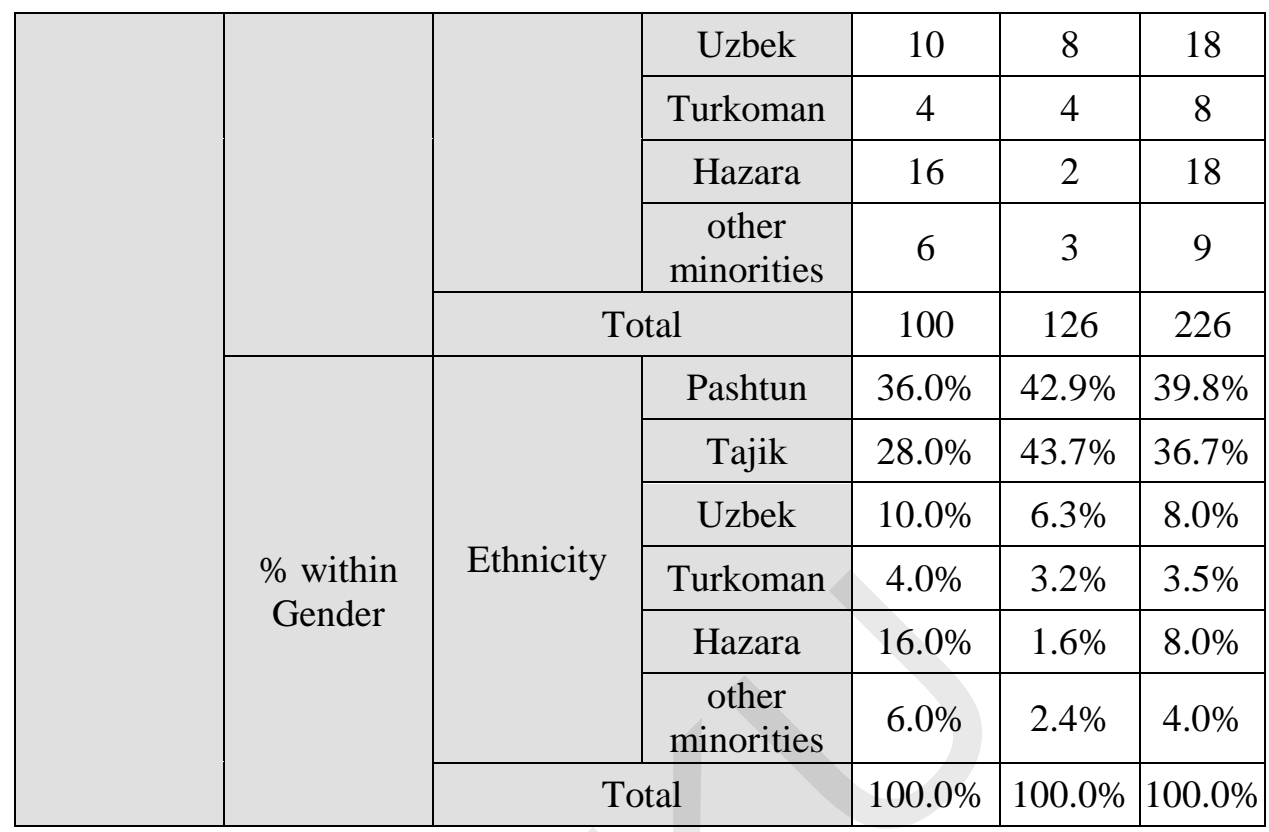

In cross tabulation of gender, ethnicity and preferred exochthonous language (selecting a foreign language for second language learning) reveal interesting preferential relation among these strata. 23\% selected no preference for a foreign language. In this no preference group male and females are equal the combined strength of Pashtun and Tajiks is $89.2 \%$ in the no preference group. It is notable that in the no preference group the minority is absent (accepting Uzbeks 5\% and Turkoman 5\%). It means that minority in Afghanistan is more inclined to learn a foreign language. The follow-up Expert Opinion, 2010 interviews also confirms this finding as the position of minorities is to consider foreign language learning a means of resisting the hegemonic domination of Pashtun and Tajik domination. One respondent expressed the emotion thus, "We live in Afghanistan a life of fear and powerlessness. Foreign language learning opens for us a path to move forward in our lives and end this life of fear." However, gender-wise Pashtun and Tajiks (the major groups in this category) $42 \%$ female Pashtuns and $57 \%$ male Pashtun differs slightly from $47 \%$ female Tajiks and $43 \%$ male Tajiks. This discrepancy indicates that among Pashtuns males are more attracted to English language while among Tajiks females do not prefer to learn any foreign language. The category of English language is the most popular category in the survey as $46.9 \%$ of Afghans chose it. Ethnicity based stratification of this category reveals that 26\% female Pashtuns and 30\% male Pashtuns like English language. Among Tajiks the gap between genders is wider as $19 \%$ female Tajiks and 53\% males chose to learn English language. The gap between males and females is $4 \%$ point and that of Tajiks is $34 \%$ point. In contrast to no preference 
category, the ratio of Pashtun (28\%) is less than Tajiks (38\%). So we conclude that non-Pashtuns prefer learning a foreign language more than Pashtuns. Other minorities (excluding Hazara, Uzbeks and Turkomans) predominantly opt for Learning English language as $44 \%$ of these minorities have prioritized English over other languages (33\% opting French and 22\% German). While Russian was a popular language in 1970s, none chose it in this study as their preferred language. In the sample of Afghan Language Planning Survey, 2010 the Hazara stood at $8 \%$ of the sample size, however, in preference for English language they are $14 \%$ of the category. Further, among Hazara females (24\%) against males (3\%) predominantly prefer English as their first choice. The questionnaire's data generated the following table of standard deviation and mean values for the Likert scale (where 1 shows strong disagreement and is the minimum value, 5 shows strong agreement and it is the maximum value while 3 shows neutrality).

Table 9: Language Planning and Response Mean and Std. Deviation

Mean Std. Deviation

\begin{tabular}{l|c|c|}
\hline $\begin{array}{l}\text { Language can become cause of conflict and disunity in } \\
\text { Afghanistan }\end{array}$ & 4.31 & .874 \\
\hline $\begin{array}{l}\text { Single official and national language would promote } \\
\text { national unity in Afghanistan }\end{array}$ & 2.35 & 1.365 \\
\hline $\begin{array}{l}\text { Promotion of Dari and Pashto is necessary for national } \\
\text { unity of Afghanistan }\end{array}$ & 3.53 & 1.491 \\
\hline $\begin{array}{l}\text { Promotion of all indigenous languages is important for } \\
\text { national unity of Afghanistan }\end{array}$ & 3.96 & 1.129 \\
\hline $\begin{array}{l}\text { Learning of foreign languages is important for friendly } \\
\text { relations with other states }\end{array}$ & 4.09 & 1.073 \\
\hline $\begin{array}{l}\text { Out of all foreign languages, English language has the } \\
\text { best chance of spreading in Afghanistan }\end{array}$ & 4.07 & .950 \\
\hline $\begin{array}{l}\text { Making English the official language of Afghanistan } \\
\text { would resolve inter-ethnic competition and promote } \\
\text { national integration of Afghanistan. }\end{array}$ & 3.47 & 1.300 \\
\hline $\begin{array}{l}\text { English language promotes the career of an Afghan } \\
\text { nationally }\end{array}$ & 3.49 & 1.252 \\
\hline $\begin{array}{l}\text { English language promotes the career of an Afghan } \\
\text { internationally }\end{array}$ & 4.03 & 1.113 \\
\hline $\begin{array}{l}\text { English language promotes the economy of } \\
\text { Afghanistan }\end{array}$ & 4.03 & 1.125 \\
\hline
\end{tabular}




\begin{tabular}{l|c|c|}
\hline $\begin{array}{l}\text { English language promotes quality education in } \\
\text { Afghanistan }\end{array}$ & 4.00 & 1.240 \\
\hline $\begin{array}{l}\text { English language promotes information and } \\
\text { communication in Afghanistan }\end{array}$ & 4.00 & 1.149 \\
\hline $\begin{array}{l}\text { Naming public spaces in English language is a sign of } \\
\text { development in Afghanistan }\end{array}$ & 4.09 & 1.213 \\
\hline $\begin{array}{l}\text { English language promotes participation in cyber } \\
\text { space and social networking }\end{array}$ & 3.94 & 1.242 \\
\hline $\begin{array}{l}\text { English language increases tolerance toward Western } \\
\text { culture and ideology }\end{array}$ & 4.02 & 1.204 \\
\hline $\begin{array}{l}\text { English language would bring cultural improvement in } \\
\text { Afghanistan }\end{array}$ & 3.97 & 1.277 \\
\hline $\begin{array}{l}\text { English language would modernize the governance in } \\
\text { Afghanistan }\end{array}$ & 4.00 & 1.236 \\
\hline $\begin{array}{l}\text { English language would decrease extremist ideologies } \\
\text { of Afghans }\end{array}$ & 4.18 & 2.960 \\
\hline $\begin{array}{l}\text { English language would improve legislation process in } \\
\text { Afghanistan }\end{array}$ & 3.95 & 1.217 \\
\hline $\begin{array}{l}\text { English language would improve the judicial process } \\
\text { in Afghanistan }\end{array}$ & 3.93 & 1.213 \\
\hline $\begin{array}{l}\text { English language would empower the marginilaized } \\
\text { segments of Afghanistan. }\end{array}$ & 3.92 & 1.154 \\
\hline $\begin{array}{l}\text { English language learning would make Afghans } \\
\text { economic, political and social slaves of the West }\end{array}$ & 2.13 & 1.329 \\
\hline $\begin{array}{l}\text { English language would destroy indigenous languages } \\
\text { of Afghanistan }\end{array}$ & 2.04 & 1.303 \\
\hline $\begin{array}{l}\text { English language learning is a sin } \\
\text { Intervention by authorities in language related issues } \\
\text { unips in the resolution of conflict and promotion of }\end{array}$ & 4.04 & 1.072 \\
\hline $\begin{array}{l}\text { Language and economic grievances are related } \\
\text { in solving the language related problems }\end{array}$ & 4.08 & 1.027 \\
\hline \begin{tabular}{l} 
Political and language grievances are related \\
\hline
\end{tabular} & 4.05 & 1.104 \\
\hline anding hocial, economic and political problems help & 1.100 \\
\hline
\end{tabular}




\begin{tabular}{|c|c|c|}
\hline Social and language grievances are related & 4.04 & 1.115 \\
\hline $\begin{array}{l}\text { Actual field study of the whole target population by } \\
\text { neutral and experienced researchers is needed to } \\
\text { determine the nature of language related problems. }\end{array}$ & 4.03 & 1.105 \\
\hline $\begin{array}{l}\text { Guiding principal of language policy planning should } \\
\text { be the advancement of cultural and linguistic diversity } \\
\text { in Afghanistan. }\end{array}$ & 4.12 & 1.168 \\
\hline $\begin{array}{l}\text { Sufficient human and material resources should be } \\
\text { allotted to the solution of language related grievances. }\end{array}$ & 4.04 & 1.261 \\
\hline $\begin{array}{l}\text { The language related facilities be accessible and } \\
\text { available to the whole population without } \\
\text { discrimination. }\end{array}$ & 3.96 & 1.158 \\
\hline $\begin{array}{l}\text { Language related decision making body should have } \\
\text { sufficient representation of experts. }\end{array}$ & 4.00 & 1.157 \\
\hline $\begin{array}{l}\text { Language related decision making body should have } \\
\text { sufficient representation of the target language } \\
\text { community. }\end{array}$ & 4.07 & 1.170 \\
\hline $\begin{array}{l}\text { Authorities should treat language as a basic human } \\
\text { right. }\end{array}$ & 4.20 & 1.038 \\
\hline $\begin{array}{l}\text { Actual field study of the whole target population by } \\
\text { neutral and experienced researchers is needed to } \\
\text { determine the nature of language related problems. }\end{array}$ & 4.05 & 1.130 \\
\hline $\begin{array}{l}\text { A policy about language should bring national and } \\
\text { international unity/integration in Afghanistan. }\end{array}$ & 4.16 & 1.176 \\
\hline $\begin{array}{l}\text { The spread of English in Afghanistan is due to the } \\
\text { support of the English speaking states. }\end{array}$ & 3.99 & 1.123 \\
\hline Valid N (listwise) & & \\
\hline
\end{tabular}

The strongest agreement in this table concurs with the cue, "Language can become cause of conflict and disunity in Afghanistan" with a mean value of 4.31 that overall the respondents strongly agree with the statement. It has an $\sigma$ of .874 making the statement fall between 3.873 and 4.747 lying comfortably close to strong agreement. The most disagreeable statement in the list is, "English language learning is a sin". It evoked a mean value of 2.03 meaning it borders on disagreement. However, the $\sigma$ of 1.306 makes it fall between 2.683 and 1.377 that makes the response to the statement decisively close to disagreement. 


\section{Conclusions and Recommendations}

\section{Conclusions}

To sum, the paper overviewed language planning in Afghanistan to ascertain the role of foreign languages in the perceived development, unity and prosperity. The language planning was studied from two perspectives (a) historical and (b) contemporary. The historical perspective showed close relation between the promotion/demotion of a foreign language and the closeness/distance between Afghanistan and the source state. Whenever a state invested in Afghanistan through economic and political resources, the language of that state found favourable ground to flourish. The case of English has seen both the favourable periods (Habibullah-Zahir Shah period and later in the refugee camps of Pakistan) and unfavourable period (during PDPA rise). So, when the study revealed that Afghans overwhelmingly favoured English over other foreign languages (Russian, French and German), it was not a surprising result. However, the stratification of responses revealed that while the minorities overwhelmingly supported foreign language cultivation in Afghanistan, the dominant ethnolinguistic groups (Dari speaking Tajiks and Pashto speaking Pashtuns) had significant portions who felt threatened by foreign languages generally and English language specifically.

\section{Recommendations}

Keeping in view the findings of this paper, the following steps are recommended:

1. Language planning in the multilingual Afghanistan with a history of ethnolinguistic tensions is a ticking bomb and the best way to avoid its explosion is to institute a high powered body with constitutional protection.

2. The authority should take language in the context of ethnic tensions and conflict and should design a comprehensive plan to solve armed conflicts side by side with addressal of language related issues.

3. As the participants overwhelming agree that economic problems relate to language related grievances, therefore, planning for addressal of economic disparity and marginalization need to include language planning component.

4. As the solution of social, economic and political grievances are linked to language related grievances therefore, a comprehensive approach to reconciliation and addressal of grievances should be adopted and it is to be insured that their implication do no marginalize the language of any group. 
5. Promotion of linguistic diversity and advancement of culture (especially of minority language groups and the marginalized in Afghanistan) is not a fancy concept that only advanced states can afford. It is a necessity for Afghanistan (as the results of the survey also reveal).

6. The removal of barriers is a vital step for the perfection language planning (making it inclusive for all Afghans).

7. Representation of stakeholders especially the routinely neglected and marginalized is the pre-condition for work on improvement of the existing language planning in Afghanistan.

8. The shift from viewing multilingualism as problem and viewing it as a resource for development requires a big social change. But its importance is great as without change in popular (and especially policy makers') attitude language planning cannot succeed.

9. As Afghanistan has not undergone a comprehensive census, therefore, it is necessary to first conduct a comprehensive, factual, transparent and neutral census.

10. English or any foreign language is to be equally available to all without any discrimination and barrier. 


\section{References}

Ahmad, A., \& Khan, A. (2016). Integration Through Language in the PakAfghan Borderland: The Interplay of past legacies, present realities and future scenarios. Central Asia Journal, 79(winter), 33-51.

Ahmed, S., \& Institute for Global Dialogue. (2001). State and society in Afghanistan : historical antecedents and contemporary determinants. Braamfontein, South Africa: Institute for Global Dialogue.

Crystal, D. (2000). Language death. Cambridge: Cambridge University Press de Saussure, F. (1915). Course de Linguistic Generale (W. Baskin, Trans.).

Dunne, M., Pryor, J., \& Yates, P. (2005). Becoming a Researcher: A research companior for the social sciences. Berkshire: Open University Press \& McGraw-Hill Education.

Dupree, N. H. (2002). Cultural heritage and national identity in Afghanistan. Third World Quarterly, 23(5), 977-989. doi: 10.1080/0143659022000028549

Dupree, N. H., \& Gouttierre, T. E. (2001). Chapter 2. The Society and its Environment A Country Study: Afghanistan (pp. 28-70). Baton Rouge, LA: Claitor's Pub. Division Library of Congress.

Ekanayake, S. B. (2004). Education in Doldrums: Afghan Tragedy (2nd ed.). Peshawar: Al-Azeem Printing Concern.

Ferguson, G. (2006). Language Planning and Education. Edinburgh: Edinburgh University Press.

Government of Afghanistan. (1935). Salnameh Kabul. Kabul: Anjoman-e-Adabi.

Government of Afghanistan. (1945-46). Almanach De Caboul: Da Kabul Kalani. Kabul: Da Pukhto Tolana.

Habibi, A. H. (1967). The Two Thousand Years Old Langauge of Afghanistan: The Mother of Dari Language (An Analysis of the Baghlan Inscription). Kabul: Government Printing Press.

Lenin, V. I. (1964). Critical Remarks on the National Question V. I. Lenin Collected Works Volume 20, December 1913-August 1914 (Vol. 20, pp. 17-52). Moscow: Progress Publishers. (Reprinted from: 1977). 
Mac Giolla Chriost, D. (2003). Language, Identity and Conflict: A comparative study of language in ethnic conflict in Europe and Eurasia. New York: Routledge.

Miskelly, M., \& Noce, J. (Eds.). (2002). Political Theories for Students. New York: Gale Group.

Muneeb. (2002). Waqaye Mukhtasar Afghanistan Peshawar: Muassissaye Intisharat AlAzhar.

Phillipson, R. (1992). Linguistic Imperialism. London: Oxford University Press.

Sadat, M. H. (March 2004). History of education in Afghanistan. Reliefweb. http://reliefweb.int/report/afghanistan/history-education-afghanistan

Spolsky, B. (2004). Language Policy. Cambridge: Cambridge University Press.

Stalin, J. V. (1953 [1913]). Marxism and the National Question J.V. Stalin Works: From Marx to Mao (1907-1913) (Vol. 2, pp. 300-382). Moscow Foreign Languages Publishing House.

Tarzi, M. (1334 AH). Mu'uallim-i Hikmat asar-i Mahmud Tarzi. kabul: Matba'ah-i Hurufi.

Voloshinov, V. N. (1973). Marxism and the Philosophy of Language. New York London: Seminar Press.

Wak Foundation for Afghanistan (WFA). (July 1999). The Ethnic Composition of Afghanistan. Peshawar: Khatiz Organization for Rehabilitation (KOR).

Wardhaugh, R. (1987). Languages in competition. Dominance, diversity and decline. Oxford: Basil Blackwell. 